2010s-42

\title{
Race of Recipient and Support for Welfare in Canada
}

\author{
Allison Harell, Stuart Soroka
}

\begin{tabular}{c}
\hline Série Scientifique \\
Scientific Series
\end{tabular}

Montréal

Septembre 2010

(C) 2010 Allison Harell, Stuart Soroka. Tous droits réservés. All rights reserved. Reproduction partielle permise avec citation du document source, incluant la notice (C).

Short sections may be quoted without explicit permission, if full credit, including (C) notice, is given to the source.
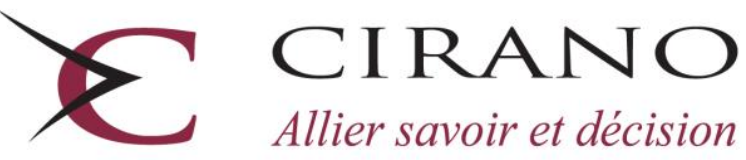

Allier savoir et décision

Centre interuniversitaire de recherche en analyse des organisations 


\section{CIRANO}

Le CIRANO est un organisme sans but lucratif constitué en vertu de la Loi des compagnies du Québec. Le financement de son infrastructure et de ses activités de recherche provient des cotisations de ses organisations-membres, d'une subvention d'infrastructure du Ministère du Développement économique et régional et de la Recherche, de même que des subventions et mandats obtenus par ses équipes de recherche.

CIRANO is a private non-profit organization incorporated under the Québec Companies Act. Its infrastructure and research activities are funded through fees paid by member organizations, an infrastructure grant from the Ministère du Développement économique et régional et de la Recherche, and grants and research mandates obtained by its research teams.

\section{Les partenaires du CIRANO}

Partenaire majeur

Ministère du Développement économique, de l'Innovation et de l'Exportation

\section{Partenaires corporatifs}

Banque de développement du Canada

Banque du Canada

Banque Laurentienne du Canada

Banque Nationale du Canada

Banque Royale du Canada

Banque Scotia

Bell Canada

BMO Groupe financier

Caisse de dépôt et placement du Québec

Fédération des caisses Desjardins du Québec

Gaz Métro

Hydro-Québec

Industrie Canada

Investissements PSP

Ministère des Finances du Québec

Power Corporation du Canada

Raymond Chabot Grant Thornton

Rio Tinto

State Street Global Advisors

Transat A.T.

Ville de Montréal

\section{Partenaires universitaires}

École Polytechnique de Montréal

HEC Montréal

McGill University

Université Concordia

Université de Montréal

Université de Sherbrooke

Université du Québec

Université du Québec à Montréal

Université Laval

Le CIRANO collabore avec de nombreux centres et chaires de recherche universitaires dont on peut consulter la liste sur son site web.

Les cahiers de la série scientifique (CS) visent à rendre accessibles des résultats de recherche effectuée au CIRANO afin de susciter échanges et commentaires. Ces cahiers sont écrits dans le style des publications scientifiques. Les idées et les opinions émises sont sous l'unique responsabilité des auteurs et ne représentent pas nécessairement les positions du CIRANO ou de ses partenaires.

This paper presents research carried out at CIRANO and aims at encouraging discussion and comment. The observations and viewpoints expressed are the sole responsibility of the authors. They do not necessarily represent positions of CIRANO or its partners. 


\title{
Race of Recipient and Support for Welfare in Canada *
}

\author{
Allison Harell ${ }^{\dagger}$, Stuart Soroka
}

\begin{abstract}
Résumé / Abstract
Cet article utilise une approche expérimentale novatrice pour examiner la façon dont les images racisées influencent les attitudes à l'endroit de l'État providence. Alors que des recherches américaines pointent une forte racialisation dans les attitudes en faveur des politiques de redistribution et de l'assistance sociale, de telles études demeurent encore rares au sein d'autres réalités nationales. Dans le contexte canadien, nos résultats suggèrent que le soutien à l'endroit des politiques de redistribution est moins élevé lorsque les bénéficiaires appartiennent aux autochtones (plutôt qu'aux blancs ou à d'autres groupes raciaux). Ainsi, comme aux Etats-Unis, les opinions face à l'assistance sociale sont étroitement liées à la perception de la race des bénéficiaires, ainsi qu'au type de l'avantage reçu.
\end{abstract}

Mots clés : Assistance sociale, autochtones, race et ethnie, opinion publique

Drawing on a unique experimental design, this paper examines the ways in which racialized images influence attitudes toward redistributive policy. While work in the US points to a strong racialization of welfare attitudes, little research explores the ways in which race may structure attitudes about welfare elsewhere. In the Canadian context, our results suggest that support for redistribution is lower when recipients are Aboriginal than when they are portrayed as white or from another racial minority. As we have seen in the US, then, support for welfare is related to perceptions about the race of the recipient, as well as the type of benefit received.

Keywords: Social assistance, Aboriginals, Race and Ethnicity, Welfare, Public Opinion

\footnotetext{
${ }^{*}$ We would like thank the Centre interuniversitaire de recherche en analyse des organisations (CIRANO) for their financial, technical and infrastructure support, Jim Engle-Warnick for invaluable help with the conception and design of the experiment, and Keith Banting for comments on an earlier draft.

†Département de science politique, Université du Québec à Montréal.

* Department of Political Science, McGill University and CIRANO.
} 
One of the defining features of industrialized democracies in the $20^{\text {th }}$ century was the evolution of the modern welfare state. The structure of specific programs varies from country to country, of course. But all industrialized nations are now actively involved in a wide range of social welfare programs, including employment insurance for the unemployed, social security and pensions for seniors, health care for some if not all citizens, and social assistance programs for the poor.

A subset of social assistance programs, commonly referred to as "welfare", have been amongst the most hotly contested. That is, whereas there is typically strong public support for most other social welfare programs, support for welfare itself is more divided. In the US context, one reason for low levels of support is that perceptions of social assistance for the poor are heavily racialized, (Bobo and Kleugal 1993; Gilens 1995, 1996a, 1996b, 2000; Winter 2008; although see Sniderman et al. 1997). Who is receiving help from the state may matter as much as what exactly they are getting.

We examine this possibility in the Canadian context. More specifically, we present results from a unique experimental design that examines support for welfare while varying the race of individual welfare recipients. The experiment allows us to isolate, then, the effect of race on welfare attitudes. Welfare "vignettes" are designed to further test whether racial effects are amplified when cash benefits are involved compared to social services. Results suggest that race does indeed matter to welfare support in Canada, though perhaps not quite in the way we might anticipate given the existing US literature. We discuss these results as they pertain to the literature on racial diversity and welfare; we also suggest that our experimental design provides a powerful framework that can be used to analyze how recipient characteristics affect attitudes towards a wide range of public policies, both within and across countries. But first, we review the existing literatures connecting racial and ethnic diversity to support for redistributive policy.

\section{Support for Redistribution in Multi-Ethnic Societies}

Public support for the welfare state tends to be fairly widespread (Tang 1997). However, a growing backlash against these programs in the 1980s and 1990s led to a flourishing research agenda into the determinants of public support for social welfare programs, and especially those programs related to "welfare" proper (Korpi 1983; Cook and Barret 1992; Schneider and Jacoby 2005b). At 
the individual level, self-interest and ideology appear to be dominant explanatory factors (Hasenfeld and Rafferty 1989; Bobo 1991; Feldman and Zaller 1992). Those who tend to benefit from specific programs tend to be more supportive of them, (e.g. low-income earners support for unemployment insurance, senior support for social security). In addition, those who espouse more egalitarian values also tend to be more supportive of the welfare state. For example, Bobo (1991) notes that those who place a higher emphasis on social responsibility rather than individualism are more likely to support redistribution, and that those who tend to espouse these values in the US also tend to be the people who benefit from such programs (e.g. those with lower incomes; Blacks).

Along with individual characteristics, research has also examined how public support varies across welfare state regimes (Esping-Anderson 1990; Papadakis and Bean 1993; Andres and Heien 2001; Blekesaune and Quadagno 2003). Esping-Anderson's (1990) influential distinction between social-democratic, conservative and liberal welfare states has led to specific expectations about the bases of support for redistributive policy. In universal programs, characterizing social democratic welfare states like those in Scandinavia, the "decommodification" of welfare benefits, according to Esping-Anderson, creates the broadest support for such programs. In contrast, liberal states like the regime in the US often have targeted, means-tested programs which are only accessed by the poor. The result is a stigmatization around recipients receiving such benefits, and lower overall support. ${ }^{1}$

Empirical evidence supports these conclusions. Even after controlling for individual level variables, country differences in support for redistribution tend to remain (Papadakis and Bean 1993; Andres and Heien 2001; Blekesaune and Quadagno 2003; Larsen 2008). And while public support does not mirror perfectly onto Esping-Anderson's original country classification, liberal regimes - especially the United States - show lower levels of support for redistribution of wealth (Papadakis and Bean 1993: 234-235; Shapiro and Young 1989; Larsen 2008). These findings link closely with individual analyses suggesting that self-interest (i.e. one's access to or potential need for benefits) relates to support for redistribution (see above, as well as Johnston et al. 2010; Soroka and Wlezien 2008; Kam and Nam 2008; Wlezien and Soroka, N.d.). In liberal states where benefits are targeted, widespread support is less likely. 
It is nevertheless true that within-country variation in support for redistribution remains - variation, that is, that cannot be accounted for by either self-interest or egalitarianism. In the following sections, we examine what we know about how citizens react to services for the poor, focusing primarily on the types of benefits received and who is receiving them.

\section{Welfare versus Social Services}

There are two main types of benefits: cash benefits and services. Whereas cash benefits serve directly as income, services, such as government-funded job counseling or retraining, focus on providing individuals the support they need to find employment to generate income. While the word "welfare" can be used to refer to a myriad of programs (Cook and Barret 1992: Ch. 1), it is usually associated (at least in the US) with specific programs aimed at providing cash (and cash-like) benefits to the poor (Ellwood 1988).

This distinction is important because of the role that discourses around selfsufficiency and dependence play in debates surrounding welfare in the US (Heclo 1986; Iyengar 1990; Fraser and Gordon 1994; Misra et al. 2003; Somers and Brock 2005). There is a dominant, and according to Fraser and Gordon (1994: 325) even "pathological", view of welfare as creating a dependency on the state. Those who rely on welfare to support themselves are viewed as responsible for their situation, due to lack of a work ethic or moral character (Golding and Middleton 1982; Smith and Stone 1989; Henry et al 2004; Somers and Brock 2005). Furthermore, their use of social assistance programs is argued to breed such personal characteristics. By giving people something for nothing, so it goes, they have no motivation to work and become a drain on the whole system. ${ }^{2}$

This logic of dependency is intimately tied to the distinction between benefits and services. Whereas cash benefits for the poor are viewed as handouts, services are viewed as more legitimate because they encourage self-sufficiency: they provide people the tools to work. Not surprisingly, while the two series clearly move in parallel over time, public support for spending on welfare is consistently lower than support for spending on services for the poor (Smith 1987; Rasinski 1989; Cook and Barret 1992; Soroka and Wlezien 2010). In Canada, research has shown a parallel pattern when citizens are asked about welfare spending versus spending for services on the poor (Harell, Soroka and Mahon 2008) - a first sign of the possibility that the difference between 
providing services and cash transfers to the poor is of relevance in Canada as well.

\section{Race, Responsibility and Deservingness}

What drives this dominant discourse around dependency in the US, and can it be transported to other liberal welfare states like Canada? One of the recurring themes in the debate around support (or rather a lack of support) for welfare is the role that race plays. As several authors have noted, welfare in the American context is race-coded (Gilens 1995, 1996a, 1996b, 1999; Mendelberg 2001; Schram et al. 2003; Winter 2006; Mendelberg 2001). While programs like social security promoted integration among White middle class (male) workers through a national, universal program structure, programs for the poor like the AFDC were targeted at an increasingly feminized and disproportionately Black underclass (Lieberman 1998; Williams 2004).

The dominant discourse around poverty portrayed in the media reinforces the racialized stigma around welfare recipients in the US. Gilens (1996a; 1999) shows that when it comes to media portrayals of the poor, Black recipients are substantially overrepresented compared to their actual program usage. Blacks tend to be portrayed not only disproportionately in stories about welfare, but they often appear in the least sympathetic stories: stories about unemployed adults (Gilens 1996a) and in stories about unpopular welfare topics like dependency (Clawson and Trice 2000; Misra et al 2003). The race frame is perpetuated in educational textbooks that similarly overrepresent Blacks when addressing poverty (Clawson and Kegler 2000, Clawson 2002).

It should not be surprising then that Americans believe that more Blacks are on welfare than actually are (Gilens 1999: 68) and that attitudes toward Blacks can partly explain lower levels of support (Gilens 1995; 1996b; 1999; Nelson 1999; Frederico 2005; Lee and Roemer 2006; Winter 2008). The link between race and welfare is well described by Winter, who argues:

This process is controlled by the interaction between the structure of citizens' cognitive representations of race and gender - their race and gender schemas - and the structure that political elites lend to issues through framing. Frames impose structure on political issues, and when that structure matches the cognitive representation, or schema, for a social category (such as race and gender), that schema will likely govern comprehension and evaluation of the issues (Winter 2008: 141). 
In other words, citizens are likely to hold specific beliefs about groups that rely on negative and prejudicial stereotypes that view differences between ingroups and outgroups as fundamental, unequal and negative (ibid, 37-41).

The negative and unequal dimensions of the Black-White schema in the US relies heavily on a history of racial discrimination and prejudice that views Blacks as lazy, unambitious, and somehow responsible for their social, political and economic inequality (Kinder and Sears 1981; Kleugal 1990; Gilens 1995; Sidanius et al 1996; Nelson 1999). In fact, Nelson shows that not only do attitudes toward Blacks affect welfare opinions, but "external attributions for racial inequality were the single most powerful predictor of welfare opinion, eclipsing similar beliefs about the poor" (1999: 353). When it comes to welfare, then, the view of Blacks as responsible for their poverty and lacking the moral qualities to get themselves out combines with the overwhelming view of welfare as a Black phenomenon. The result, as Winter's theory suggests, is that racial schema coalesce with a dominant frame of welfare as dependency to create low levels of support for redistribution.

Clearly, racial attitudes are at least in part able to explain low levels of support for welfare in the US. It remains to be seen whether racial cues are as important in predicting support for services, however. Services do not fit as neatly with the pathology that has developed around welfare. Services can be viewed as self-help (skill development, job retraining) whereas "welfare" is viewed as a hand-out (cash transfers) to a (perhaps undeserving) underclass. One might expect that when social assistance is framed in terms of services, racial attitudes will play a less important role.

There has been relatively little work that directly tests whether racial attitudes can account for the gap in support for services for the poor compared to welfare. One exception is work by Sniderman and colleagues (1997), who, using an experimental manipulation, vary recipient characteristics (Blacks vs. new immigrants from Europe), deservingness, and the type of social assistance (welfare vs. job training). They find the expected results for both deservingness and program type, though contrary to expectations they also find that Whites are more supportive of programs for Blacks than for new immigrants from Europe. Sniderman and colleagues argue that those without prejudicial attitudes are more likely to be consistent when provided with other discriminating information. When race is an issue, such individuals may try to actively reject racially intolerant responses. 
This work provides fairly strong support that positive descriptions of social assistance recipients can promote support, especially for training. The experiment focuses on support for what are for most Americans two different out-groups, however (Blacks versus immigrants from Europe); our intention here is to focus on differences in support for in-groups versus out-groups, defined only by race (and not immigrant status). That is, the key test below of how race affects support for redistribution is a manipulation in which recipients are either White or members of a racialized minority, but are all citizens.

\section{Support for Welfare in the Comparative Context}

Racial attitudes and cues are clearly important in explaining welfare attitudes in the US, yet we know far less about whether such processes occur in other countries (although see Shapiro and Young 1989). In Europe, there has been increasing interest in how rising immigration levels influence welfare state support (Bommes and Geddes 2000; Sales 2002; Crepaz 2008; Soroka et al. 2006). Issues around immigration in Europe are highly racialized ${ }^{3}$, yet little is known about how racial diversity affects specific welfare policies outside the US context. The US is the archetype of a liberal welfare state, and its comparatively low levels of support for welfare is often tied to the structure of its welfare programs (which are means-tested and not universal). In addition, the racial dynamics in the US are often considered a point of exceptionalism (e.g. Goldfield 1997). The history of slavery in the US distinguishes it from other countries where racial diversity is driven by increasing immigration from non-European source countries.

In this paper, we examine the link between racial cues and welfare attitudes in Canada. The Canadian case provides interesting parallels and dissimilarities with the US. Like the US, Canada has also experienced a retrenchment of the welfare state and a shift in rhetoric around poverty resulting from individual deficiencies rather than structural barriers (Anton and Côté 1998; Bashevkin 2002). Its welfare state is considered liberal, although it has a wider range of

universal programs including a long-standing publicly-funded healthcare system.

In terms of income support, two main programs are available: social assistance programs and Employment Insurance (EI). Social assistance programs are administered by each province and provide financial and in-kind goods and 
services to cover basic living expenses to people in financial need. These programs would typically be considered "welfare". The programs are meanstested, meaning that individuals must demonstrate both financial need and participate in one or more employment activities as a condition of continued eligibility. There are four categories of funding: employable persons, singleparent families, persons with disabilities, and persons with multiple barriers to employment. The EI program is a federal program available to people who lose their jobs, providing a maximum of $\$ 457$ a week for up to 50 weeks. The program is based on insurable income, with additional benefits available to those in low-income categories and with children. The EI program, then, is more universal that social assistance programs, but additional benefits are available to low-income earners.

Similar to the US, Canada also has a highly diverse population. There are historic Black, Chinese and Aboriginal communities, although a greater proportion of the ethnic and racial diversity of the country results from immigration over the past thirty years. Canada's largest minority groups are of Chinese and Southeast Asian descent, although there are significant communities, especially in Montreal and Toronto, of Caribbean-descent. This ethnic diversity is an important component of Canada's self-image as a multicultural country and plays an important role in its political narrative and history (Kymlicka 1989; Reitz 1988; Uberoi 2008).

In terms of public attitudes, comparative work suggests that Canadians are particularly open to both immigration and multiculturalism (Ward and Masgoret 2008; Adams 2007). Over time, public attitudes toward diversity have become more positive as well (Harell 2009; Berry and Kalin 1995; Wilkes et al. 2008). This is not to say that there are not real material and social inequalities (Day 2000; Abu-Laban and Gabriel 2002; Razack 2002). Persistent discrimination based on race certainly exists (Razack 2002; Henry and Tator; Roberts and Doob 1997; Reitz 1988). This is perhaps most obvious for Aboriginal Canadians who have a distinct, colonial relationship to Canadians of European-origin and who continue to face serious economic and social disadvantage in Canada (Juteau 2000; Razack 2002).

Canada, then, provides an interesting case in which to explore how welfare attitudes are affected by race, given its similarities and differences to the US. Population diversity in Canada is driven more by immigration, and its social programs tend to be more universal than in the US. But Canada shares with 
the US a liberal welfare regime, an increasingly neo-liberal view of the causes of poverty, and a diverse population. And public support for welfare versus services for the poor mirror almost directly the dynamics in the US (Harell et al 2008). In the following sections, we explore the extent to which these low levels of support for welfare can be attributed to, in short: (H1) differences between welfare assistance with cash payments versus service-based social assistance, and (H2) the race of recipients.

\section{Data and Methods}

The data used to assess these hypotheses are drawn from a series of experiments carried out at the experimental economics laboratory at the Centre interuniversitaire de recherche en analyse des organisations (CIRANO) in Montreal, Quebec. The preliminary experiments used here were carried out with 182 university students, recruited through an on-going recruitment process at CIRANO which advertises for both English and French-speaking participants at the campus career centres of four Montreal universities, as well as in one of McGill University's campus newspapers. A random selection of English-speaking participants in the participant pool were invited to participate in the experiments described here. Participants received $\$ 20$ for their participation in one of ten sessions held from March 26 to April 8, 2010.

The sample characteristics are provided in Appendix Table 1. The final sample is roughly split between men and women, with the majority of respondents in the 22-29 age group range (57\%). Most of the participants come from families where at least one parent has finished a university degree. Reflecting in part the diversity of universities in the Montreal area, the student sample has a relatively high proportion of visible minority respondents $(51 \%)$, non-citizens $(40 \%)$, and first generation immigrants $(65 \%)$. Our "majority" sample, i.e., White Canadian citizens, is thus limited in size; that said, we have a relatively unique opportunity to explore not only White reactions to non-White recipients, but to examine how minority group members react to those who share (and do not share) their ethnic or racial background as well.

The experiment design is based on factorial analysis (Rossi and Nock 1982).

Participants are exposed to a series of vignettes (short stories) that describe an individual's circumstances and the types of benefits they are eligible for. With each vignette, the participant sees a color photo of the individual 
described in the vignette. The primary treatment is the racial background of the person in the photograph and the name of the individual in the vignette. For every policy vignette of interest, participants see either a White face with an Anglo-Saxon or French first name or a minority face (Black, MiddleEastern, or Aboriginal) with a name common to that ethnic group in Canada. Unlike the US literature, we do not limit the distinction to White-Black contrasts; rather, our sample is intended to better reflect the ethnic and racial cleavages present in Canada.

In total, each participant sees 28 separate vignettes in random order, three of which focus specifically on social assistance. In addition to the race of the individual described in the vignette, we also randomly vary whether we ask about welfare assistance with a cash benefit or service-based social assistance (see appendix for text of the three welfare vignettes). ${ }^{4}$ The recipients in each case were previously employed. In the Canadian context, this would make them eligible for a host of programs, including Employment Insurance benefits, as well as additional benefits through provincial social assistance programs as "Employable Persons" should they demonstrate financial need. That all recipients were previously employed should make our experiment a particularly tough test for racial effects - these are all relatively "deserving" candidates for assistance, i.e., candidates for whom re-entry into the workforce eventually seems likely. (The full text of all three welfare vignettes is included in the Appendix.)

The remaining 25 vignettes ask about a variety of other public policies scenarios. Twelve of these include a racial manipulation; these deal with immigration, health care, education, union benefits, and childcare. The remaining thirteen vignettes are "filler," and include a photograph of a White individual in order to distract the participant from the questions of interest, and also to ensure that the distribution of photos any participant sees is more representative of the actual racial composition of Montreal. After each vignette, the participant is asked whether they strongly support, somewhat support, somewhat oppose or strongly oppose the person described in the vignette benefiting from the policy.

Compared to traditional telephone survey items, a vignette-based approach in a lab setting is a useful — and possibly more accurate - alternative means of capturing attitudes relating to racism. Vignettes allow people to make specific judgments that are likely easier to report compared to feelings about abstract 
values (see, e.g., Alexander and Becker 1978). Furthermore, the lab setting means that respondents are able to respond alone, to a computer, rather than to an interviewer, reducing the likelihood of social desirability bias or other interviewer effects. Given increasing social pressure to refrain from overt forms of racism, asking directly about racial attitudes can induce social desirability biases in responses. It can also contaminate responses to other questions by inadvertently cuing racial considerations. We are able to assess support for policies, and then isolate the difference that racial cues make through a comparison of treatment groups.

\section{Results}

Table 1 shows results from an ANOVA exploring both the direct and interactive effects of race and program type. The unit of analysis is each response to a welfare vignette - 540 responses in total, that is, 3 responses for each of 180 participants. $^{5}$ Because the distribution of the welfare support variable for all cases explored here is heavily skewed - $56 \%$ of the responses are "strongly support", and another $31 \%$ are "somewhat support" — we rely on a binary version of support for our analyses, where "strongly support" is coded as 1 , and all other values are coded as $0 .{ }^{6}$

Table 1. ANOVA: Support, on Race of Recipient and Program Type

\begin{tabular}{|c|c|c|c|}
\hline & Partial SS & $\mathrm{df}$ & $\mathrm{F}$ \\
\hline Model & 81.454 & 190 & $2.90 * *$ \\
\hline Respondent & 69.062 & 181 & $2.58 * *$ \\
\hline Female & .324 & 1 & 2.19 \\
\hline Cash/Programs & 1.930 & 1 & $13.07 * *$ \\
\hline Female $*$ Cash & .927 & 1 & $6.28 *$ \\
\hline Race of Recipient & 1.896 & 3 & $4.28 * *$ \\
\hline Race $*$ Cash & .099 & 3 & .22 \\
\hline Residual & 51.530 & 349 & \\
\hline$\overline{\text { Total }}$ & 132.983 & 539 & \\
\hline
\end{tabular}

Note that Table 1 reports results from a standard "within-subject" ANOVA, in which we include respondent IDs as a variable, capturing a good portion of the variance across respondents, and then explore the within-respondent variance in welfare support across different manipulations. Those 
manipulations include race (Race of Recipient) and program type (Cash/ Programs), as well as an interaction between them. The ANOVA also separates out the effect of recipients' gender, so that we can better gauge the effect of race on it own. Indeed, we allow for an interaction between gender and program type as well. (We do not allow for the full three-way interaction here only because preliminary tests suggested that no three-way interaction existed.)

Results suggest that roughly $52 \%$ of the variance is accounted for by differences across respondents. ${ }^{7}$ Of the remaining variance, program type and race of the recipient account for another $3 \%$ each. These effects are small but statistically significant. There is in addition an interactive effect of gender and program type, where the positive effect of programs versus welfare payments is greater for the female recipients than the male ones; there is no evidence of an interactive effect between race of the recipient and the type of program.

Table 2. Predicted Support, by Race of Recipient and Program Type

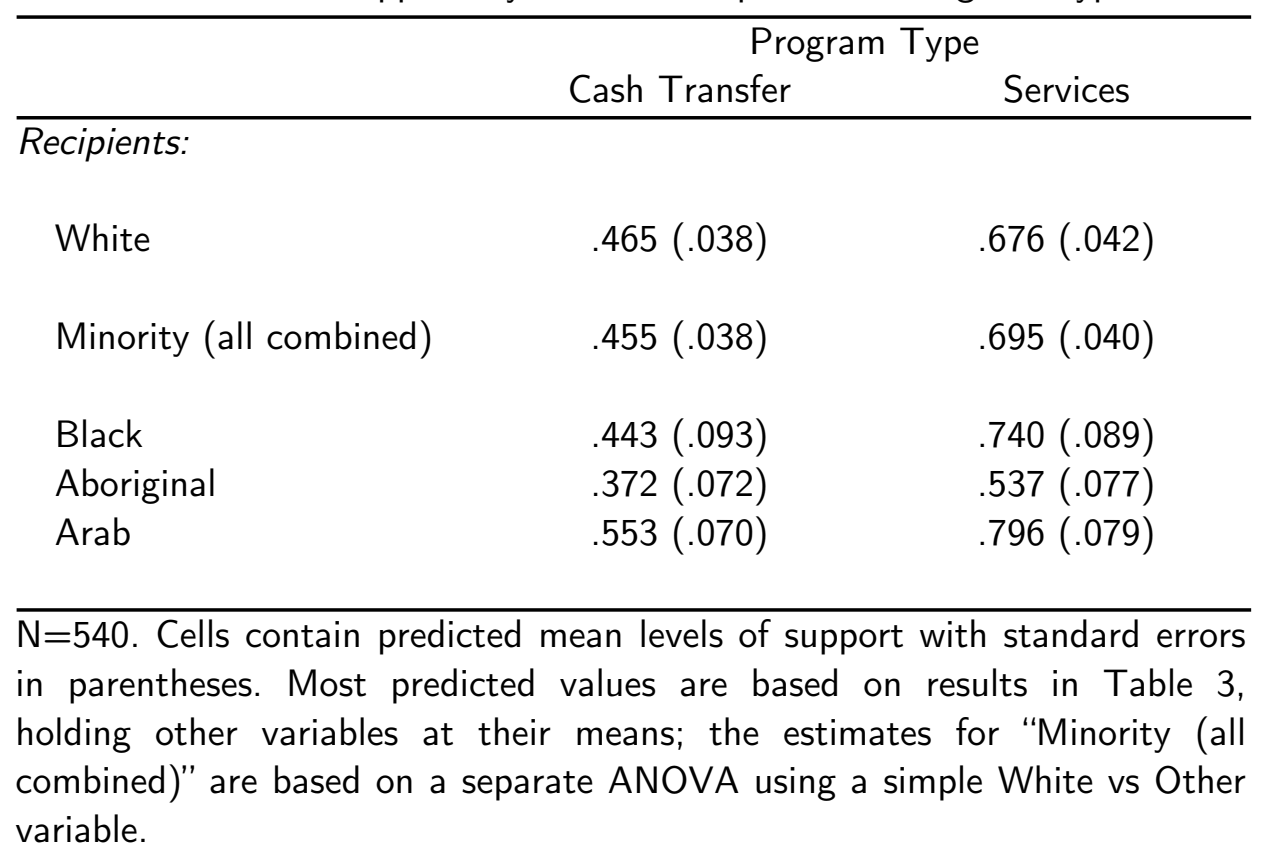

Findings in Table 1 are made more readily interpretable in Table 2, which shows the predicted mean levels of support based on the underlying regression in Table 1. The first two rows show mean levels of support for White versus minority recipients (taken as a whole). There are, in short, no significant differences in levels of support for White versus racial minority recipients. For cash transfers, mean support for White recipients is .465, while for 
minority recipients it is .455 ; for services, mean support for White recipients is .676, while for minority recipients it is .695. In line with our expectations, then, support is clearly greater for services than for cash transfers; differences in support for White versus minority recipients are, overall at least, not at all evident.

The following rows in Table 2 show mean levels of support for the three different racial minority groups taken separately, and here there are some interesting differences. The Black and Arab recipients here receive no less support than do the White recipients - for the Black recipient, .443 and .740

for cash and services respectively, and .553 and .796 for the Arab recipient. If anything, support for these recipients is somewhat higher than for Whites. The story is very different for the Aboriginal recipient, however. Support for cash transfers is substantially lower (.372), as is program support (.537). We discuss this finding in more detail below.

Where support for Black and Arab recipients is concerned, note that the relatively small effect of race overall is not a product of the diversity of our sample (which is just less than 50\% White). While the US literature on race and welfare has focused almost exclusively on Whites' views of Black recipients, a broader psychological view of welfare attitudes might suggest that people are less willing to support benefits to outgroup members more generally (see. e.g., Sherif et al, 1964; Tafjel and Turner, 1986). We can of course test this possibility directly. However, results do not suggest a significant interaction between the race of the recipient and the race of the survey participant. That is, we find no evidence that examining only Whites reveals greater hostility toward visible minority recipients. Equally important, and made possible by our diverse sample, we find no evidence that visible minority respondents show greater favoritism to other minority recipients. ${ }^{8}$ This finding holds regardless of whether we examine split samples based on respondents' backgrounds, or if we include interactions between respondents' and recipients' racial backgrounds. ${ }^{9}$ There is, then, just one consistent, significant racial effect in these data: Aboriginal recipients receive less support.

\section{Conclusion}

When it comes to the public bases of support for redistribution, previous work in the US has suggested that limited support for welfare is driven in part 
because welfare recipients are (often wrongly) assumed to be Black. In this paper, we tested whether the race of the recipient had similar, dampening effects on support for both cash-based and service-based assistance in Canada. Results clearly suggest that race matters to support for redistributive policy in Canada. This is true above and beyond the effect of welfare versus social services; and, indeed, racial effects are as evident for services as they are for welfare involving cash payments.

That said, the direction of racial effects in this experiment was not quite as expected. We found substantially lower support for an Aboriginal recipient a sign, we suspect, of a particularly negative association between Aboriginal Canadians and issues of dependency. But we found no similar effect for the two visible minority recipients. These findings thus provide a rather complex picture of the effects of recipient race on support for redistribution. Part of this complexity may stem from our relatively unique sample, which includes a high proportion of visible minority participants. Yet, we found no evidence of particularly negative attitudes of Whites toward other minority recipients (or, conversely of visible minorities toward Whites). Yet, regardless of the participants' racial background, our analyses consistently point to a negative effect when welfare recipients were portrayed as Aboriginal.

We believe this variation reveals an important distinction in the racial scripts that dominate Canadian political discourse. While both the Black and Arab recipients are likely viewed as immigrants, Aboriginals quite clearly are not. Discourses around Aboriginal communities in Canada parallel more closely the racialized discourse around African-Americans in the United States. There are clearly important differences between the two, of course. But stereotypes about Aboriginal Canadians often revolve around issues of dependency and poverty, and are heavily imbued with images of moral insufficiencies (Green 2006; Harding, 2005; Royal Commission on Aboriginal Peoples 1996). These negative and derogatory stereotypes are amplified by the real material and educational inequalities between Aboriginal communities and other Canadians (Juteau 2000; Kendall 2001.) Immigrants, on the other hand, tend to be more highly educated than native-born Canadians, and while there are clearly problems with racial discrimination, the larger discourse about immigrants tends to be more positive (Harell 2010). These differences appear to be reflected in our results. 
The effects that we find might also be muted compared to those found in US studies because we do not manipulate "deservingness." That is, while our racial manipulations may appeal indirectly to ideas about deservingness, all three of our vignettes involve recipients who are comparatively "deserving": all three have prior work experience and are laid off through no obvious fault of their own, so the image portrayed in each vignette is not of someone who is "leeching" off the system. We expect if we manipulate deservingness (e.g. target long-term welfare recipients with few skills and an unstable employment history), the racial effects we find here might shift somewhat. Yet, the portrayal of welfare recipients in our vignettes, we feel, provides a particularly difficult test for racial effects. It is notable, then, that despite what we believe to be relatively deserving recipients, and despite working with a very diverse (and educated) student sample, results still suggest differences in support for welfare based on the race of the recipient.

Our findings also point more broadly to the value for this vignette-based approach in exploring relationships between race and welfare policy support, to the need for further analysis of the relationship between Aboriginal Canadians and welfare attitudes in Canada, and perhaps also to the potential importance of an intergroup framework for understanding support for redistribution. While the types of benefits looms large, questions about shared background provide an interesting, and complex, basis for support that might allow the US findings to be more usefully tested across a variety of contexts. 


\section{Appendix}

\section{Vignettes}

1) White vs. Black Female

1a: [Sarah/Lachanda] is a single mother of two young children, aged 8 and 12 years old. She was a part-time administrator, but lost her job due to cutbacks at the local hospital. [Sarah/Lachanda] has been without work for some time, and is now eligible for welfare assistance. Under current rules, she will receive $\$ 450$ every week for up to 50 weeks.

1b: [Sarah/Lachanda] is a single mother of two young children, aged 8 and 12 years old. She was a part-time administrator, but lost her job due to cutbacks at the local hospital. [Sarah/Lachanda] has been without work for some time, and is now eligible for government-sponsored job counseling and, if necessary, government-funded job retraining.

2) White vs. Aboriginal Male

2a) [Jean-Luc/Wayne] is married and has one seven-year-old child. The restaurant where he had been working for the past seven years recently closed. [Jean-Luc/Wayne] has been without work for some time, and is now eligible for welfare assistance. Under current rules, he will receive $\$ 1600$ a month for up to one year.

2b) [Jean-Luc/Wayne] is married and has one seven-year-old child. The restaurant where he had been working for the past seven years recently closed. [Jean-Luc/Wayne] has been without work for some time, and is now eligible for social assistance, including government-funded job retraining.

3) White vs. Arab Male

3a) [Anthony/Amir] is 27 years old. He grew up in Quebec. After high school, he trained to be an automobile mechanic. Last year, the garage he worked at closed. [Anthony/Amir] has been without work for some time, and is now eligible for welfare assistance. Under current rules, he will receive $\$ 900$ a month for up to 50 weeks.

3b) [Anthony/Amir] is 27 years old. He grew up in Quebec. After high school, he trained to be an automobile mechanic. Last year, the garage he worked at closed. [Anthony/Amir] has been without work for some time, and is now eligible for free job counseling services through the province. 
Appendix Table 1. Respondent Characteristics

\begin{tabular}{llc}
\hline Variable & Category & $\mathrm{N}$ \\
\hline Gender & Male & 95 \\
& Female & 87 \\
\hline Age & $18-21$ & 30 \\
& $22-29$ & 103 \\
& $30-39$ & 33 \\
& $40+$ & 13 \\
\hline Racial Background & White & 88 \\
& Asian & 30 \\
& Black & 18 \\
& SE Asian & 10 \\
& Hispanic & 12 \\
& Arab & 24 \\
\hline Language & English & 81 \\
& French & 48 \\
& Other & 44 \\
& Multiple & 9 \\
\hline Mother's Education & HS & 46 \\
& Cegep/Coll & 33 \\
& University & 103 \\
\hline Father's Education & HS & 40 \\
& Cegep/Coll & 24 \\
& University & 118 \\
\hline Citizens & Yes & 109 \\
& No & 73 \\
\hline Vote (non-citizens incl) & Liberal & 70 \\
& Conservative & 16 \\
& NDP & 27 \\
& BQ & 8 \\
& Green & 15 \\
& Other & 2 \\
& None & 41 \\
& NA/ND & 2 \\
\hline & & \\
& & \\
& &
\end{tabular}




\section{Notes}

${ }^{1}$ Interestingly, Sniderman and colleagues (1996) have shown that when targeted programs are framed in universal ways, they garner greater support.

2 It should be noted that little evidence of this culture of dependence is actual found among welfare recipients (Schneider and Jacoby 2005a).

${ }^{3}$ For a review of how immigrants in the European context are subject to specific racial discourses, see Silverstein (2005).

${ }^{4}$ A full description of all the vignettes are available from the authors.

${ }^{5}$ Six vignettes were not asked due to a small computer error. This had no effect on the randomization of the design.

6 Note, however, that all the general patterns explored below remain when support is left in the original 4-point support/oppose scale.

7 The differences across respondents are specified very generally in this standard within-subjects ANOVA, though note those differences are the product of some combination of individual-level factors, including, for instance, education, income, race and citizenship.

8 Based on the self-reported racial background collected during a brief postexperimental survey, respondents were categorizes as either White or "visible minority" (a term used in the Canadian census to refer to racial minority groups, but excluding Aboriginal Canadians). If we analyze the samples separately, predicted support for White recipients receiving cash benefits was .51 and for services was .72 among White respondents. Support for the visible minority recipients were similar, or even slightly higher in the case of services, while Aboriginal recipients were at .41 for cash benefits and .57 for services. A very similar pattern emerged among visible minority recipients, with Aboriginal recipients receiving the lowest support for cash benefits and services (.34 and .51 respectively).

9 In a separate set of analyses not reported here, we create a variable that matches the recipient and respondents' racial background. When Whites judged White recipients or visible minorities other visible minorities, predicted support is .44 for cash benefits and .70 for services. When respondents judge an outgroup member (either White for visible minorities, or visible minority for Whites), support is, if anything, slightly higher (.51 and .80 respectively) although these differences are not statistically significant. However, consistent with previous tables, Aboriginal recipients receive significantly lower levels of support for both cash benefits and services (.36 and .53 respectively). 


\section{Bibliography}

Abu-Laban, Y. \& Gabriel, C. (2002) Selling Diversity: Immigration, Multiculturalism, Employment Equity and Globalization. Peterborough, ON, Broadview Press.

Adams, Michael. Unlikely Utopia: The Surprising Triumph of Canadian Pluralism. Toronto: Viking Canada, 2007.

Alexander, Cheryl and Henry Jay Becker. 1978. "The Use of Vignettes in Survey Research." Public Opinion Quarterly 42: 93-104.

Andres, Hans-Jurgen and Thorsten Heien. 2001. "Four Worlds of Welfare State Attitudes? A Comparison of Germany, Norway and the United States." European Sociological Review 17(4): 337-356.

Anton L. Allahar and James E. Côté. 1998. Richer and Poorer: The Structure of Inequality in Canada. James Lorimer and Company: Toronto.

Bashevkin, Sylvia. 2002. Welfare Hot Buttons: Women, Work, and Social Policy in Reform. University of Toronto: Toronto.

Blekesaune, Morten and Jill Quadagno. 2003. "Public Attitudes toward Welfare State Policies." European Sociological Review 19: 415-427.

Berry, J. W. (2000) "Socio-Psychological Costs and Benefits of Multiculturalism: A View from Canada." IN Dacyl, J. W. \& Weston, C. (Eds.) Governance and Cultural Diversity. Stockholm, UNESCO and CIEFO, Stockholm University.

Berry, J. W. \& Kalin, R. (1995) "Multicultural and Ethnic Attitudes in Canada: An Overview of the 1991 National Survey." Canadian Journal of Behavioural Science 27: 301 .

Billiet, J., Maddens, B. \& Beerten, R. (2003) "National Identity and Attitude toward Foreigners in a Multinational State: A Replication." Political Psychology 24: 241-257.

Bloemraad, I. (2006) Becoming a Citizen: Incorporating Immigrants and Refugees in the United States and Canada. Berkeley CA: University of California Press.

Bobo, Lawrence. 1991. Social Responsibility, Individualism, and Redistributive Policies. Sociological Forum. 6(1): 71-92.

Bobo, Lawrence and James Kleugel. 1993. "Opposition to Race-Targeting: SelfInterest, Stratification Ideology, or Racial Attitudes." American Sociological Review 58(4): 443-464.

Bommes, Michael and Andrew Geddes (Eds). 2000. Immigration and Welfare: Challenging the Borders of the Welfare State. London: Routledge.

Clawson, Rosalee. 2002. "Poor People, Black Faces." Journal of Black Studies 32(3): $352-361$.

Clawson, Rosalee and Elizabeth Kegler. 2000. "Race Coding of Poverty in American Government College Textbooks." Howard Journal of Communication 11(3): 179-188.

Clawson, Rosalee and Rakuta Trice. 2000. "Poverty as We Know It: Media Potrayals of the Poor" Public Opinion Quarterly 64: 53-64.

Cook, Fay Lomax and Edith Barrett. 1992. Support for the American Welfare State: The Views of Congress and the Public. New York: Columbia University Press.

Crepaz, Marcus. 2008. Trust beyond Borders: Immigration, the Welfare State and Identity in Modern Societies. Ann Arbor: University of Michigan Press. 
Day, Richard J. F. Multiculturalism and the History of Canadian Diversity. Toronto: University of Toronto Press, 2000.

Ellwood, David. (1988) Poor Support: Poverty in the American Family. New York:Basic Books.

Esping-Anderson, Gøsta. 1990. The Three Worlds of Welfare Capitalism. Princeton NJ: Princeton University Press.

Feldman, Stanley and John Zaller. 1992. "The Political Culture of Ambivalence: Ideological Responses to the Welfare State." American Journal of Political Science 36: 268-307.

Fraser, Nancy and Linda Gordon. 1994. "Dependency Demystified: Inscriptions of Power in a Keyword of the Welfare State." Social Politics 1: 4-31.

Frederico, Christopher. 2005. "Racial Perceptions and Evaluative Responses to Welfare: Does Education Attenuate Race-of-Target Effects?" Political Psychology 26(5): 683-697.

Gilens, Martin. 2000. Why Americans Hate Welfare: Race, Media, and the Politics of Antipoverty Policy. Chicago: University of Chicago Press.

- 1996a. "Race and Poverty in America: Public Misperceptions and the American News Media." Public Opinion Quarterly 60(4): 515-541.

- 1996b. "Race Coding' and White Opposition to Welfare." American Political Science Review 90(3): 593-604.

- 1995. "Racial Attitudes and Opposition to Welfare." Journal of Politics 57(4): 994-1014.

Goldfield, Michael. 1997. The Color of Politics: Race and Mainsprings of American Politics. New York: New Press.

Golding, Peter and Sue Middleton. 1982. Images of Welfare: Press and Public Attitudes to Poverty. Oxford, England: Martin Robertson.

Green, Joyce. 2006. From Stonechild to Social Cohesion: Anti-Racist Challenges for Saskatchewan. Canadian Journal of Political Science. 39(3): 507-527.

Harding, Robert. 2005. The Media, Aboriginal People, and Common Sense. Canadian Journal of Native Studies. XXV(1): 311-335.

Harell, Allison. 2009. "Minority-Majority Relations in Canada: The Rights Regime and the Adoption of Multicultural Values." Paper presented at the Canadian Political Science Association Annual Meeting, Ottawa ON. http://cpsa-acsp.ca/ papers-2009/Harell.pdf.

Harell, Allison, Stuart Soroka and Adam Mahon. 2008. "Is Welfare a Dirty Word? Canadian Public Opinion on Social Assistance Policies." Policy Options 29(8): 53-56.

Hasenfeld, Yeheskel and Jane Rafferty. 1989. "The Determinants of Public Attitudes Toward the Welfare State." Social Forces 67(4): 1027-1048.

Heclo, H. 1986. "General welfare and two American political traditions." Political Science Quarterly 101: 179-196.

Henry, P.J., Christine Reyna and Bernard Weiner. 2004. "Hate Welfare but Help the Poor: How Attributional Content of Stereotypes Explains the Paradox of Reactions to the Destitute in America." Journal of Applied Psychology 34(1): 34-58.

Henry, Frances, and Carol Tator. 2002. Discourses of Domination: Racial Bias in the 
Canadian English-Language Press. Toronto: University of Toronto Press.

Hurwitz, Jon and Mark Peffley. 1997. "Public Perceptions of Race and Crime: The Role of Racial Stereotypes." American Journal of Political Science 41(2): 375-401.

Iyengar, Shanto. 1990. "Framing Responsibility for Political Issues: The Case of Poverty." Political Behavior 12(1): 19-40.

Jasso, Guillermina, and Karl-Dieter Opp. 1997. "Probing the Character of Norms: A Factorial Survey Analysis of the Norms of Political Action." American Sociological Review 62:947-964.

Johnston, Richard, Keith Banting, Will Kymlicka and Stuart Soroka. 2010. "National Identity and Support for the Welfare State." Forthcoming in the Canadian Journal of Political Science 43(3).

Juteau, Danielle. (2000). Patterns of Social Differentiation in Canada. Understanding their Dynamic and Bridging the Gaps. Canadian Public Policy. 26 (Supplement): S95-S107.

Kam, Cindy and Yunju Nam. 2008. "Reaching Out or Pulling Back: Macroeconomic Conditions and Public Support for Social Welfare Spending." Political Behavior 30 (2): 223-258.

Kendall, Joan. 2001. Circles of Disadvantage: Aboriginal Poverty and Underdevelopent in Canada. American Review of Canadian Studies. 31(1): 43-59.

Kinder, Donald and David Sears. 1981. "Prejudice and Politics: Symbolic Racism versus Racial Threats to the Good Life." Journal of Personality and Social Psychology 40:414-431.

Kluegel, James. 1990. "Trends in Whites' Explanations of the Gap in Black-White Socio-Economic Status, 1977-1989." American Sociological Review 55: 512-525.

Korpi, Walter. 1983. The Democratic Class Struggle. London: Routledge.

Kymlicka, Will. 1989. Liberalism, Community and Culture. New York: Clarendon Press,.

Kymlicka, Will. 1995. Multicultural Citizenship: A Liberal Theory of Minority Rights. Oxford: Clarendon Press.

Larsen, Christian Albrekt. 2008. "The Institutional Logic of Welfare Attitudes." Comparative Political Studies 41(2): 145-168.

Lee, Woojin and John E. Roemer. 2006. Racism and Redistribution in the United States: A Solution to the Problem of American Exceptionalism. Journal of Public Economics.90(6-7): 1027-1052.

Lieberman, Robert. 1998. Shifting the Color Line: Race and the American Welfare State. Harvard University Press.

Mendelberg, Tali. 2001. The Race Card: Campaign Strategy, Implicit Messages, and the Norm of Equality. Princeton University Press.

Misra, Joya, Stephanie Moller and Marina Karides. 2003. "Envisioning Dependency: Changing Media Depictions of Welfare in the 20 ${ }^{\text {th }}$ Century." Social Problems 50 (4): 482-504.

Nelson, Thomas. 1999." Group Affect and Attribution in Social Policy Opinion." Journal of Politics 61(2): 331-362.

Papadakis, Elim and Clive Bean. 1993. "Popular Support for the Welfare State: A Comparison Between Institutional Regimes." Journal of Public Policy 13(3): $227-254$. 
Popkin, Susan. 1990. "Welfare: Views from the Bottom." Social Problems 37(1): 64-79.

Rasinski, Kenneth A. 1989. "The Effect of Question Wording on Public Support for Government Spending." Public Opinion Quarterly 53:388-94.

Razack, Sherene, ed. Race, Space and the Law: Unmapping a White Settler Society. Toronto: Between the Lines, 2002.

Reitz, Jeffrey. "Less Racial Discrimination in Canada, or Simply Less Racial Conflict?: Implications of Comparisons with Britain." Canadian Public Policy 14 (4): 424-41.

Roberts, Julian and Anthony Doob. 1997. "Race, Ethnicity and Criminal Justice in Canada." Crime and Justice 21: 469-.

Rossi, Peter and Steven Nock. 1982. Measuring Social Judgments: The Factorial Survey Approach. Newbury: Sage Publications.

Royal Commission on Aboriginal Peoples. 1996. Final Report. Ottawa: Canada Communications Group.

Sales, Rosemary. 2002. "The Deserving and the Undeserving? Refugees, Asylum Seekers and Welfare in Britain." Critical Social Policy 22(3): 456-478.

Schneider, Saundra and William Jacoby. 2005a. "A Culture of Dependence? The Relationship Between Public Assistance and Public Opinion." British Journal of Political Science 33(2): 213-231.

Schneider, Saundra and William Jacoby. 2005b. "Elite Discourse and American Public Opinion: The Case of Welfare Spending." Political Research Quarterly 58 (3): 367-379.

Schram, Sanford, Joe Soss, and Richard Fording. (eds) 2003. Race and the Politics of Welfare Reform. Ann Arbor: University of Michigan Press.

Shapiro, Robert Y. and John T. Young. 1989. "Public Opinion and the Welfare State: The United States in Comparative Perspective." Political Science Quarterly 104 (1): 59-89.

Sherif, M., Harvey, O. J., White, B. J., Hood, W. R., \& Sherif, C. W. 1961: Intergroup Conflict and Cooperation: The Robbers Cave Experiment. Norman: University of Oklahoma Book Exchange.

Sidanius, J. Pratto, F. \& Bobo, L. 1996". Racism, Conservatism, Affirmative Action and Intellectual Sophistication: A Matter of Principled Conservatism or Group Dominance?" Journal of Personality and Social Psychology 70: 476-490.

Silverstein, Paul. 2005. Immigrant Racialization and the New Savage Slot: Race, Migration and Immigration in the New Europe. Annual Review of Anthropology. 34: 363-384.

Smith, Tom W. 1987. "That Which We Call Welfare by Any Other Name Would Smell Sweeter: An Analysis of the Impact of Question Wording on Response Patterns." Public Opinion Quarterly 51:75-83.

Smith, Kevin and Lorene Stone. 1989. "Rags, Riches, and Bootstraps: Beliefs about the Causes of Wealth and Poverty." Sociological Quarterly 30(1): 93-107.

Sniderman, Paul, Edward Carmines, Geoffrey Layman and Michael Carter. 1996. "Beyond Race: Social Justice as a Race Neutral Ideal." American Journal of Political Science 40(1): 33-55. 
Somers, Margaret and Fred Block. 2005. "From Poverty to Perversity: Ideas, Markets and Institutions over 200 Years of Welfare Debate." American Sociological Review 70(2): 260-287.

Soroka, Soroka and Christopher Wlezien. 2010. Degrees of Democracy: Politics, Public Opinion and Policy. Cambridge MA: Cambridge University Press.

- 2008. "On the Limits to Inequality in Representation." PS: Political Science and Politics, April 2008: 319-27.

Soroka, Stuart, Richard Johnston and Keith Banting. 2006. "Immigration and Redistribution in a Global Era." In Sam Bowles, Pranab Bardhan and Michael Wallerstein, eds. Globalization and Egalitarian Redistribution. Princeton University Press and Russell Sage Foundation.

Tang, K.L. 1997. "The Case for the Privatization of Social Welfare: Three Decades of Public Opinion Evidence from Great Britain and the United States." International Journal of Social Welfare 6(1): 34-43.

Tajfel, Henry, and John C. Turner. "The Social Identity Theory of Intergroup Behavior." In Psychology of Intergroup Relations, edited by William G. Austin and Stephen Worchel. Chicago: Nelson-Hall, 1986.

Uberoi, V. (2008) Multiculturalism and the Canadian Charter of Rights and Freedoms. Political Studies, 1-23.

Ward, Colleen, and Anne-Marie Masgoret. "Attitudes toward Immigrants, Immigration and Multiculturalism in New Zealand: A Social-Psychological Analysis." International Migration Review 42(1): 227-48.

Weldon, S. A. (2006) The Institutional Context of Tolerance for Ethnic Minorities: A Comparative, Multilevel Analysis of Western Europe. American Journal of Political Science 50: 331-349.

Wilkes, R., Guppy, N. \& Farris, L. (2008) "No Thanks, We're Full: Individual Characteristics, National Context, and Changing Attitudes Toward Immigration." International Migration Review 42: 203-329.

Williams, Linda. 2004. The Constraint of Race: Legacies of White Skin Privilege in America. University Park PA: Penn State University Press.

Winter, Nicholas. 2006. Beyond Welfare: Framing and the Racialization of White Opinion on Social Security. American Journal of Political Science. 50(2): 400-420.

- 2008. Dangerous Frames: How Ideas about Race and Gender Shape Public Opinion. Chicago IL: University of Chicago Press.

Wlezien, Christopher and Stuart Soroka N.d. "Inequality in Public Responsiveness?" Forthcoming as Chapter 10 in Peter Enns and Christopher Wlezien, eds., Who Gets Represented?, Russell Sage Foundation. 